\title{
Interactions Between Vegetative and Floral Buds in Apple and Peach
}

\author{
W.Q. Yang' and D.M. Glenn ${ }^{2}$ \\ U.S. Department of Agriculture-Agricultural Research Service, Appalachian \\ Fruit Research Station, 45 Wiltshire Road, Kearneysville, WV 25430
}

Additional index words. defoliation, deflotation, growth rate, sink competition, Malus domestica, Prunus persica, growth regulators

\begin{abstract}
The osmotic potential and development of apple (Malus domestica Borkh.) and peach [Prunus persica $(\mathrm{L}$.$) Batsch] floral and vegetative buds and tissue were determined$ pre- and postbloom. Apple and peach floral and vegetative buds were removed prebloom and the osmotic potential and bud development were measured pre- and postbloom. The osmotic potential of vegetative and floral buds was related to the phenology of bud development. Developing buds had a more negative osmotic potential than dormant buds. Leaf buds on deflorated shoots had a more negative osmotic potential than leaf buds on shoots with floral buds. However, flower buds on defoliated shoots had a less negative osmotic potential than flower buds on shoots with leaf buds.
\end{abstract}

Low osmotic potential contributes to maintenance of turgor and tolerance to low tissue water potentials (Tyree and Jarvis, 1982). This relationship has stimulated considerable work in osmotic adjustment of horticultural crops (Lakso et al., 1984; Stirling et al., 1989; Taylor et al., 1982; Young et al., 1981, 1982). Osmotic adjustment is correlated with high yield (Morgan et al., 1986), solute partitioning, and nutrient uptake (Meyer and Boyer, 1981; Thomas et al., 1991). However, Munns (1988) presented evidence that osmotic adjustment alone cannot promote growth or solute partitioning except via other processes. The osmotic potential of leaves varies diurnally, and Radin et al. (1986) demonstrated that the magnitude of this change correlated with the sink source balance in the plant. Dosskey et al. (1990) also demonstrated that the addition of a sink (in the form of mycorrhizal fungi) stimulated photosynthesis, resulting in a more negative leaf osmotic potential. These results suggest that osmotic potential is related to sink activity, and an active sink will maintain a more negative osmotic potential relative to less active sinks. Ho ( 1988) defined potential sink strength as the ability of a tissue to receive or attract assimilate, a process that generally results in a more negative osmotic potential in the plant tissue.

Flower emergence precedes leaf emergence in peach and follows leaf emergence in apple.

Received for publication 22 Apr. 1993. Accepted for publication 20 Oct. 1993. Reference to company name or product name does not imply approval or recommendation of the product by the U.S. Dept. of Agriculture to the exclusion of others that may be suitable. The cost of publishing this paper was defrayed in part by the payment of page charges. Under postal regulations, this paper therefore mus be hereby marked advertisement solely to indicate this fact.

'Graduate Research Assistant. Current address: Shaanxi Fruit Crop Research Center, Dong-Yi Rd. Xian 710061, P.R. China.

${ }^{2}$ To whom reprint requests should be addressed.
Both species rely on stored reserves for early spring growth of shoots and fruit. During this period, the flower buds compete with leaf buds for energy and nutrient reserves translocated from the storage organs. The osmotic potential of leaf buds and flower buds preceding and during budbreak has not been reported. We tested the hypotheses that during the bloom period, peach flower buds would be stronger sinks and have a more negative osmotic potential than leaf buds, whereas apple flower buds would be weaker sinks and have a less negative osmotic potential than leaf buds. In addition, we examined the effect of fruit bud removal on leaf osmotic potential and leaf bud removal on fruit bud osmotic potential.

\section{Materials and Methods}

Experiments were performed from Feb. 1991 to May 1991 using 7-year-old 'Loring' peach trees and 'Golden Delicious' and 'Red Delicious' apple trees.

Osmotic potential of flower and leaf buds (Expt. 1). Three 'Loring' peach trees and three 'Golden Delicious' apple trees were sampled. Sampling started on 26 Feb. with 5- to 10-day sampling intervals based roughly on the developmental stages of flower buds. Peach leaf buds and flower buds used were from 1-yearold fruiting wood from the upper two-thirds of the canopy. The extension shoots in the upper canopy were selected for apple, and the first two bud clusters near the base of the extension shoots were excised. All the excised materials were wrapped with parafilm immediately after excision to prevent water evaporation. They were transported at $4 \mathrm{C}$ and frozen at $-40 \mathrm{C}$ for $24 \mathrm{~h}$. After thawing, the sap from the entire bud, including the bud scale, was expressed by placing the bud in a tygon tube and closing the tube with a vice. The osmotic potential was determined by a vapor pressure osmometer (model 5500; Wescor, Logan, Utah). Units of osmolality were converted to MPa using $0.00253 \mathrm{mmol} \cdot \mathrm{kg}^{-1} \cdot \mathrm{MPa}^{-1}$. On the first sam- pling date, three to five peach flower buds and $\approx 50$ peach leaf buds adjacent to flower buds were needed to obtain $10 \mu \mathrm{l}$ of cell sap for a single determination. The number of apple flower buds and apple leaf buds needed was 3 and 30, respectively. As flower buds and leaf buds of peach and apple trees developed, fewer buds were needed, and only midposition buds of the shoots were used for measurements. We analyzed data using a paired $t$ test for each crop at each sampling date, using trees as replicates. The level of significance for the analysis of variance was $P=0.01$.

Effect of defloration on leaf bud osmotic potential (Expt. 2). Along with a control, we applied a defloration treatment to nine peach trees on 19 Mar. by removing all flower buds from an entire shoot. Twelve fruiting shoots were selected from each tree and placed randomly into three groups for periodic sampling within the tree. Leaf buds or leaves in the midshoot position were sampled 24 Mar. and 3 and 8 Apr. The leaf bud or leaf osmotic potential was determined in the same manner as in Expt. -1. We analyzed data using a paired $t$ test for each sampling date using single-tree replicates $(P=0.01)$.

Effect of defoliation on fruit bud osmotic potential (Expt. 3). Along with a control, we applied a defoliation treatment to nine peach trees on 19 Mar. 1991 by removing the leaf buds from an entire shoot. Twelve fruiting shoots were selected from each tree and placed randomly into four groups for periodic sampling within the tree. Flower buds or fruit in the midshoot position were sampled 24 Mar. and 3 and $18 \mathrm{Apr}$.

Along with a control, we applied a defoliation treatment to 11 'Red Delicious' apple trees on 12 Mar. 1991 by removing the leaf buds from an entire shoot. Eight extension shoots in the upper portion of the canopy were placed randomly into four groups for periodic sampling within the tree. Flower buds or fruit in the midshoot position were sampled 29 Mar. 8 and 29 Apr., and 8 May. The fruit bud or fruitlet osmotic potential was determined in the same manner as in Expt. 1. We analyzed data using a paired t test for each crop at each sampling date using single-tree replicates $(P=$ $0.01)$.

\section{Results}

Experiment 1. Apple leaf buds consistently had a more negative osmotic potential than flower buds at all sampling dates, indicating that they attracted and retained more solutes than flower buds (Fig. 1). In contrast, peach flower buds had a lower osmotic potential than leaf buds prebloom. However, after the leaves expanded, this relationship was reversed, and peach leaves had a lower osmotic potential than the fruitlets, indicating a reversal in the ability to attract and retain solutes.

Experiment 2. On all sampling dates following defloration on 19 Mar., peach leaf bud osmotic potential was more negative on deflorated shoots than on shoots containing both leaf and flower buds (Fig. 2).

Experiment 3. Peach flower buds on de fo- 
liated shoots, sampled prebloom 24 Mar., had less negative osmotic potential than those on nontreated trees (Fig. 3). Apple flower buds on defoliated shoots also had a less negative osmotic potential than the control before bloom. After bloom, the osmotic potential of apple and peach fruitlets on defoliated shoots was not significantly different from the respective controls.

\section{Discussion}

Our hypothesis that osmotic potential is related to sink activity implies that osmotic potential reflects the strength of competing sinks. The concept that a high osmotic concentration in plant tissue is a basic survival strategy of plant species appeared as early as 1924 (Harris et al., 1924). Few studies have related osmotic potential with sink strength. Ho et al. (1987) found that the sugar concentration inside tomato (Lycopersicon esculentum Mill.) fruit vacuoles was not determined by the supply of sugars outside the cells but was osmotically regulated by the osmotic potential of the sap within the vacuoles. Potassium salts were a major constituent of the high solute potential in the fruit vacuole. In our study, peach flower buds began visible development before leaf buds, and they had a more negative osmotic potential than leaf buds. The opposite occurred with apple flower buds, which had a less negative osmotic potential than leaf buds. The direction of change in peach and apple flower- and leaf-bud osmotic potential was linked with their phenology (Fig. 1). Scorza et al. (1991) found that the number of cells in peach fruit increased 8 fold during the prebloom period. Both apple and peach fruit are secondary sinks compared to shoot growth following bloom; their inability to compete for carbon is evident in the relationship between fruit abortion and fruit: leaf ratios (Quinlan, 1975). The nature of osmotic adjustment could simply be solute accumulation and build-up (Munns, 1988) as a result of sink activity; the magnitude of osmotic potential then reflects the metabolic activity among the various sinks. The studies of defloration and defoliation before and shortly after budbreak support the concept of sink activity for stored carbohydrates.

Defloration and defoliation techniques are commonly used as a means of altering sinksource competitions. Many studies have shown that defloration resulted in more vegetative growth (Palmer et al., 1991; Scott and Marth, 1953; Wien et al., 1973) because competitive fruit sinks were removed. In our study, peach defloration resulted in a more negative leaf osmotic potential (Fig. 2). Sink competition was also reflected in the shift of peach leaf and fruit tissue osmotic potential following bloom (Fig. 1)

In contrast to the effect of defloration on leaf osmotic potential, defoliation resulted in a less negative osmotic potential of fruit buds for peach and apple before bloom (Fig. 3). These data suggest that sink interactions cannot always be viewed simply. Apparently, the leaf bud is vital to the development of the fruit

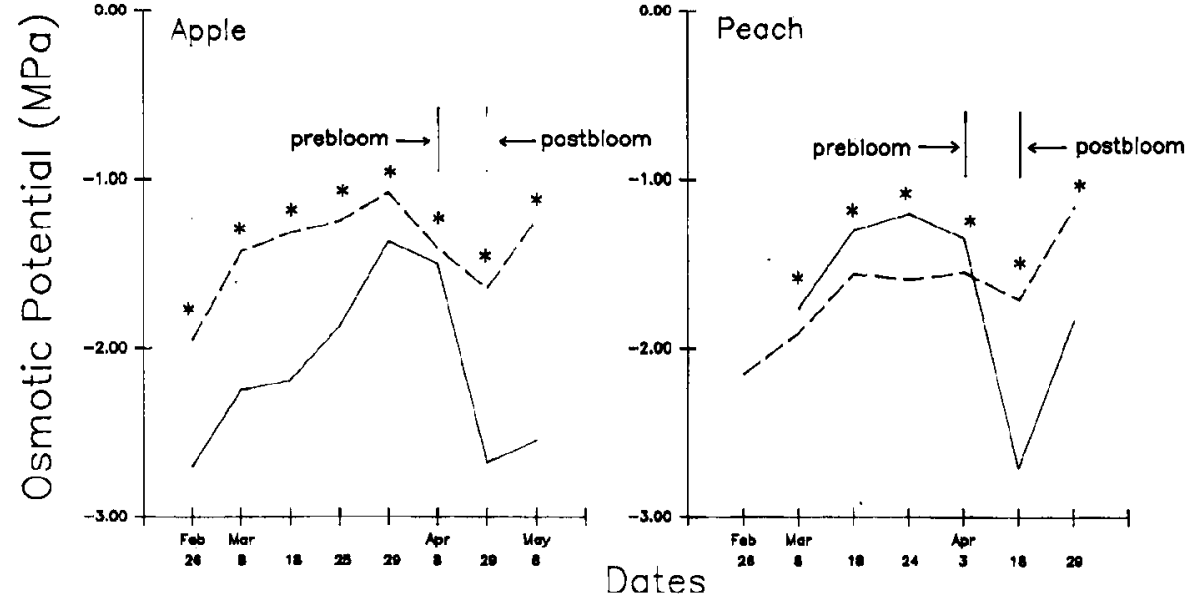

Fig. 1. The osmotic potential of flower buds and fruitlets and leaf buds and leaves at various sampling dates (Expt. 1). Treatments differ significantly as determined by test $(P=0.01)(*)$; flower buds and fruitlets (-); leaf buds and leaves (----).

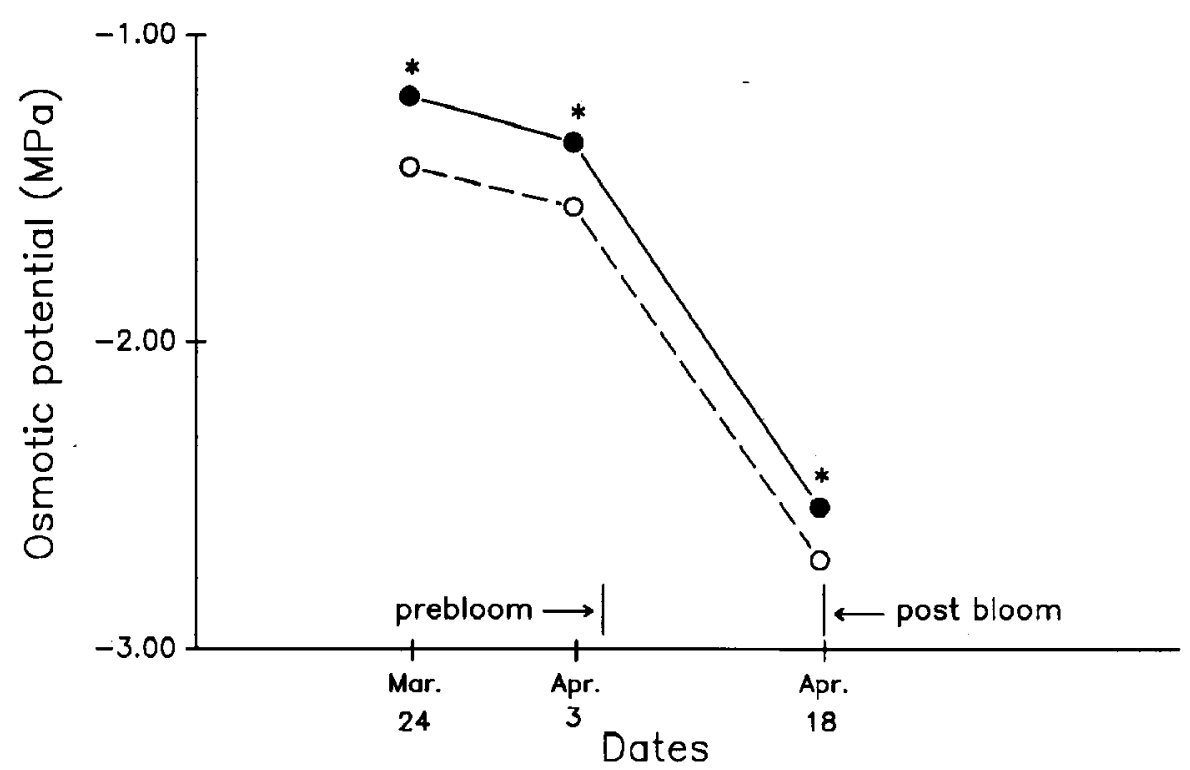

Fig. 2. The effect of defloration on the osmotic potential of peach leaf buds and leaves at three sampling dates (Expt. 2). Treatments differ significantly as determined by $t$ test $(P=0.01)(*)$; control $(-)$; defloration (----).
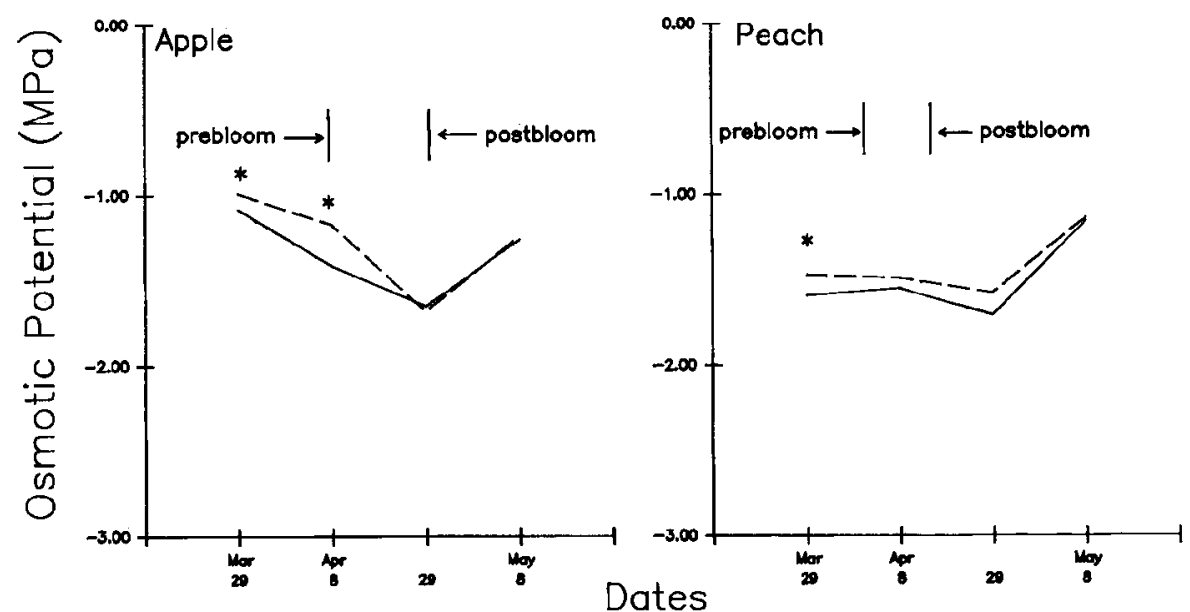

Fig. 3. The effect of defoliation on the osmotic potential of fruit buds and fruitlets at four sampling dates (Expt. 3). Treatments differ significantly as determined by $t$ test $(P=0.01)(*)$; control $(-)$; defoliation $(---)$. 
bud even though both depend on stored carbohydrates during this period.

Our data support the concept that osmotic potential is related to relative sink strength; however, sink interactions cannot always be viewed as mechanistic competition for limited reserves as Wilson (1988) suggested. We found evidence that peach floral buds depend on the presence of leaf buds. This dependence may be linked to plant growth regulator substances produced by the leaf bud.

\section{Literature Cited}

Dosskey, M.G., R.G. Linderman, and L. Boersma. 1990. Carbon-sink stimulation of photosynthesis in Douglas fir seedlings by some ectomycorrhizas. New Phytol. 115(2):269-274

Harris, J.A., R.A. Gortner, W.F. Hoffman, J.V. Lawrence, and A.T. Valentine. 1924. The osmotic concentration, specific electrical conductivity, and chloride [sic] content of the tissue fluids of the indicator plants of Tooele Valley, Utah. J. Agr. Res. 27:893-924.

Ho, L.C. 1988. Metabolism and compartmentation of imported sugars in sink organs in relation to sink strength. Ann. Rev. Plant Physiol. Plant Mol. Biol. 39:355-378.

Ho, L.C., R.I. Grange, and A.J. Picken. 1987. An analysis of the accumulation of water and dry matter in tomato fruit. Plant Cell Environ. 10:157-162.
Lakso, A.N., A.S. Geyer, and S.G. Carpenter. 1984 Seasonal osmotic relations in apple leaves of different ages. J. Amer. Soc. Hort. Sci. 109:544547.

Meyer, R.F. and J.S. Boyer. 1981. Osmoregulation, solute distribution, and growth in soybean seedlings having low water potentials. Planta 151:482-489.

Morgan, J.M., R.A. Hare, and R.J. Fletcher. 1986. Genetic variation in osmoregulation in bread and durum wheats and its relationship to grain yield in a range of field environments. Austral. J. Agr. Res. 37:449-457.

Munns, R. 1988. Why measure osmotic potential? Austral. J. Plant Physiol. 15:717-726.

Palmer, J.W., Y.L. Cai, and Y. Edjamo. 1991. Effect of part-tree flower thinning on fruiting, vegetative growth and leaf photosynthesis in 'Cox's Orange Pippin' Apple. J. Hort. Sci. 66(3):319-325.

Quinlan, J.D. 1975. Reduction of crop yield by growth competition, p. 106-109. In: H.C. Pereira (ed.). Climate and the orchard. Commonwealth Agriculture Bureaux, Slugh, England.

Radin, J.W., J.R. Mauney, and G. Gninn. 1986. Diurnal osmotic cycling in cotton leaves as an indicator of source-sink balance. Plant, Cell \& Environ. 9:349-352.

Scorza, R.L., G. May, B. Purnell, and B. Upchurch 1991. Differences in number and area of mesocarp cells between small- and large-fruited peach cultivars. J. Amer. Soc. Hort. Sci. 116:861-864,

Scott, D.H. and P.C. Marth. 1953. Effect of blossom removal on growth of newly set strawberry plants. J. Amer. Soc. Hort. Sci. 62:255-256.

Stirling, C.M., C.R. Black, and C.K. Ong. 1989. The response of groundnut (Arachis hypogaea, $\mathrm{L}$ ) to timing of irrigation. J. Expt. Bot. (40):13631373.

Taylor, A.G., J.E. Motes, and M.B. Kirkham. 1982 Osmotic regulation in germinating tomato seedlings. J. Amer. Soc. Hort. Sci. 107:387-390.

Thomas, G.R., L.B. Nina, and H.W. Thomas. 1991. Osmotic adjustment and solute constituents in leaves and roots of water-stressed cherry (Prunus) trees. J. Amer. Soc. Hort. Sci. 116:684688,

Tyree, M.T. and P.G. Jarvis. 1982. Water in tissue and cells, p. 35-77. In: O.L. Lange, P.S. Nobel, C.B. Osmond, and H. Ziegler (eds.). Physiological plant ecology II: Water relations and carbon assimilation. Springer-Verlag, New York.

Wien, H.C., R.F. Sandsted, and D.H. Wallace. 1973 The influence of flower removal on growth and seed yield of Phaseolus valgaris L. J. Amer. Soc. Hort. Sci. 98:45-49.

Wilson, J.B. 1988. A review of evidence on the control of shoot: root ratio, in relation to models. Ann. Bot. 61:433-449.

Young, E., J.M. Hard, and S.C. Wiest. 1981. Diurnal variation in water potential components and stomatal resistance of irrigated peach seedlings. J. Amer. Soc. Hort. Sci. 106:337-340.

Young, E., J.M. Hard, and S.C. Wiest. 1982. Osmotic adjustment and stomata] conductance in peach seedlings under severe water stress. HortScience 17:791-793. 